\title{
Seasonal dynamics of prokaryotes and their associations with diatoms in the Southern Ocean as revealed by an autonomous sampler
}

\author{
Liu Yan ${ }^{1,2}$, Blain Stéphane ${ }^{1}$, Crispi Olivier ${ }^{1}$, Rembauville Mathieu ${ }^{1}$, Obernosterer Ingrid ${ }^{1, *}$
}

${ }^{1}$ CNRS, Laboratoire d'Océanographie Microbienne (LOMIC)Sorbonne Université 66650 Banyuls-surMer ,France

${ }^{2}$ College of Marine Life SciencesOcean University of China Qingdao 266003 ,China

* Corresponding author : Ingrid Obernosterer, email address : ingrid.obernosterer@obs-banyuls.fr

\begin{abstract}
:
The Southern Ocean remains one of the least explored marine environments. The investigation of temporal microbial dynamics has thus far been hampered by the limited access to this remote ocean. We present here high-resolution seasonal observations of the prokaryotic community composition during phytoplankton blooms induced by natural iron fertilization. A total of 18 seawater samples was collected by a moored remote autonomous sampler over 4 months at 5-11 day intervals in offshore surface waters (central Kerguelen Plateau). Illumina sequencing of the 16S rRNA gene revealed that among the most abundant ASVs, SAR92 and Aurantivirga were the first bloom responders, Pseudomonadaceae, Nitrincolaceae, and Polaribacter had successive peaks during the spring bloom decline, and Amylibacter increased in relative abundance later in the season. SAR11 and SUP05 were abundant prior to and after the blooms. Using network analysis, we identified two groups of diatoms representative of the spring and summer bloom that had opposite correlation patterns with prokaryotic taxa. Our study provides the first seasonal picture of microbial community dynamics in the open Southern Ocean and thereby offers biological insights to the cycling of carbon and iron, and to an important puzzling issue that is the modest nitrate decrease associated to iron fertilization.
\end{abstract}




\section{Introduction}

Marine microbial communities process the fluxes of all biologically important elements. Knowledge of the functions of individual taxa and their contribution to the community performance is an important goal in microbial oceanography, but the link between taxonomy and function remains a major challenge. The spatial distribution of microbial communities and their shifts over time have illustrated the dynamics of distinct groups or taxa, and linked to environmental factors and biotic associations, these patterns have informed on the ecological niches of microbes of interest (Hanson et al., 2012; Fuhrman et al., 2015). Investigations of the genomic repertoire in combination with culture-based studies have provided detailed insights to the distinctive metabolism of members of all major microbial groups (Offre et al., 2013; Voget et al., 2015; Xing et al., 2015; Giovannoni, 2017; Kappelmann et al., 2019; Moran and Durham, 2019). This information is key for a better understanding of the microbial dynamics in the marine environment and the role of taxa in the biogeochemical cycling of elements.

Temporal observations play an important role in revealing patterns in microbial community composition and functioning. Shifts in the microbial assemblages can occur on time scales ranging from days to months (Alonso-Saez and Gasol, 2007; Gilbert et al., 2012; Ottesen et al., 2014; Lindh et al., 2015; Needham and Fuhrman, 2016; Teeling et al., 2016).

Observations carried out over multiple years have revealed annually recurring patterns of prokaryotic community composition, strongly driven by season (Fuhrman et al., 2006; Giovannoni and Vergin, 2012; Chafee et al., 2018; Lambert et al., 2019). Phytoplankton 
blooms are highly dynamic events, and they were shown to be major drivers of compositional shifts (see reviews by Buchan et al., 2014; Bunse and Pinhassi, 2017). The release of a suite of organic compounds by phytoplankton and their processing by diverse taxa is one of the driving processes (Moran et al., 2016; Mühlenbruch et al., 2018). The various interactions between phytoplankton species and microbial taxa could additionally lead to shifts in community composition (Amin et al., 2012; Lima-Mendez et al., 2015; Liu et al., 2019). Long-term observations are key to identify these patterns and to detect changes in the functioning of microbial communities due to global environmental change.

Temperate regions of the northern hemisphere are up to date privileged sites for microbial observatories, while the southern hemisphere and polar oceans are severely under-sampled (Buttigieg et al., 2018). Due to its remoteness from land and thus limited access, the Southern Ocean remains one of the least explored environments. Seasonal microbial community dynamics were mainly investigated in coastal systems with variable temporal resolution (Ghiglione and Murray, 2012; Grzymski et al., 2012; Williams et al., 2012; Luria et al., 2016). Automated instrumentation provides to date the unique access for the seasonal to annual observations of Southern Ocean sites distant from shore. BGC-Argo floats were recently used to estimate temporal shifts of major plankton groups based on optical properties (Rembauville et al., 2017). Using moored sediment traps, the seasonal changes of diatoms contributing to export flux was described in the Australian Sector of the Southern Ocean (Rigual-Hernández et al., 2016). The seasonal succession of heterotrophic prokaryotes, however, remains thus far unexplored. The aim of the present study was to provide a high-resolution description of the microbial community composition during an entire season in the Southern Ocean. Given the 
dominant contribution of diatoms to bulk phytoplankton biomass during the productive season in our study region (Lasbleiz et al., 2016; Rembauville et al., 2017, Irion et al. 2020), we further aimed to explore the associations between prokaryotic taxa and diatom species. We addressed these objectives using samples collected with an autonomous sampler and fixed with mercuric chloride in surface waters of the central Kerguelen plateau, where natural iron fertilization induces massive spring phytoplankton blooms.

\section{Results}

\section{Environmental context}

The remote autonomous sampler (RAS) was deployed at station A3, located south-east of Kerguelen Island in the Indian Sector of the Southern Ocean $\left(50.63^{\circ} \mathrm{S}, 72.06^{\circ} \mathrm{E}\right.$; overall depth 527m) from 25 October 2016 to 24 February 2017 (Fig. 1). The combined data obtained by the sensors mounted on the mooring and from the analyses of seawater collected by the RAS provided insights to seasonal changes of several environmental parameters. Temperature was $2.1^{\circ} \mathrm{C}$ at the start of the observation period in late October and steadily increased over time to reach $4.6^{\circ} \mathrm{C}$ by February 24 (Fig. 2). The concentrations of silicic acid and of combined nitrate and nitrite decreased from $20 \mu \mathrm{M}$ to $6 \mu \mathrm{M}$ and from 28 to $24 \mu \mathrm{M}$, respectively, during the first month of observation (Fig. S1). A small transient increase (up to $8 \mu \mathrm{M}$ ) in silicic acid was detectable in late December. Ammonium concentrations increased from $<0.5 \mu \mathrm{M}$ in 
early spring to up to $2 \mu \mathrm{M}$ in late December. Satellite images revealed two consecutive phytoplankton blooms, the first peaking in mid-November and the second in early January.

\section{Diatom community composition}

A total of 38 diatoms, most of them at the species level, were identified by microscopic observations of 12 samples fixed with glutaraldehyde (Table S1), and 21 species had a relative abundance $\geq 1 \%$ in at least one of the samples (Fig. 3; Table S2). The contribution of diatoms to the total carbon biomass of phytoplankton that can be detected by microscopic observations ( $>10 \mu \mathrm{m}$ ) was on average $88 \pm 9 \%$ during the sampling period, and accounted for 95\% and 91\% during the spring and summer bloom, respectively (Fig. 3). At the onset and during the first bloom, small centric diatoms such as Chaetoceros Hyalochaete ( 50\% of total diatom abundance), Thalassionema nitzschioides ( 20\%), Thalassiosira antarctica ( $5 \%$ ) and other small centrics ( 5\%) that could not be determined to the species level dominated. After the first bloom, Pseudo-nitzschia spp. increased in relative abundance and remained abundant until February 13 (range 6 - 43\%). Major contributors to the second bloom were Chaetoceros Hyalochaete ( 30\%), Pseudo-nitzschia spp. ( 35\%), small centrics ( 5\%) and Corethron inerme ( 5\%). This latter diatom species further increased in abundance (up to $20 \%$ ) during the remaining season. Other diatom species that were more abundant during summer than spring were Guinardia cylindrus (1-14\%), Proboscia alata (0.2-2\%) and Cylindrotheca closterium (0.3-14\%). 


\section{Composition of free-living and particle-attached prokaryotes}

Prokaryotic (bacterial and archaeal) community composition was determined on seawater samples fixed with mercuric chloride (see Experimental procedures). The number of sequences obtained for all samples varied between 14749 - 52 581. After subsampling to the minimum number of sequences, we obtained a total of 792 ASVs. The number of ASVs per date varied between 92 and 194 in the free-living and between 103 and 240 in the particleattached fraction. Community composition was significantly different between free-living and particle-attached prokaryotes (ANOSIM, $\mathrm{R}=0.4839, \mathrm{P}=0.001$ ) and the communities of both fractions shifted over time (Fig. S2). Alphaproteobacteria, Bacteroidetes, Gammaproteobacteria and Archaea were abundant in both size-fractions and pronounced temporal changes at the order level could be observed (Fig. S3).

For the description of the seasonal dynamics of the prokaryotic communities at the ASV level, we focus in the following on the dominant ones (relative abundance $\geq 1 \%$ in at least one sample), detected at the evenly spaced 12 time points and used for the network analysis (Fig. 4; all 19 samples are shown in Fig. S4). For free-living prokaryotes, one ASV belonging to the SAR11 clade Ia and one SUP05 ASV were abundant throughout the season (each $6-17 \%$ of relative abundance), with the exception of one date, just after the peak of the spring bloom (<3\%). During the spring bloom, the most abundant ASVs belonged to gammproteobacterial Nitrincolaceae $(\approx 36 \%)$, Pseudomonas $(\approx 20 \%)$, and SAR92 $(\approx 11 \%)$, Rhodobacterales Sedimentitalea $(\approx 11 \%)$, and Flavobacteriales Polaribacter $(\approx 17 \%)$ and 
Aurantivirga $(\approx 15 \%)$. The transition between the spring and summer bloom had abundant contributions of one Amylibacter ASV (range 8-9\%) and several Planktomarina ASVs (range 3-8\%), both belonging to Rhodobacterales, together with one Aurantivirga ASV (range 8-9\%) and one Cryomorphaceae ASV (range 1-4\%). Bacteroidetes consisted almost exclusively of subgroup Flavobacteriales, and revealed a succession among different members. ASVs belonging to NS2b, NS4 and NS9 were the most abundant ones prior to the spring bloom (together 13\%), while Aurantivirga, Polaribacter, and Ulvibacter ASVs became dominant during the peak and the decline of the spring bloom (together 51\%), and NS2b and Formosa ASVs increased towards the end of the season (together 5-12\%). Among the above described ASVs, the 9 most abundant ones (SAR11 ASV_4, SUP05 ASV_5, Nitrincolaceae ASV_1 and ASV_7, Pseudomonas ASV_2, SAR92_ASV_9, Aurantivirga ASV_6, Polaribacter ASV_10, Amylibacter ASV_8) accounted together for 36\% to 77\% of the total relative abundance during the observation period.

In the particle-attached fraction, a number of highly abundant ASVs belonged to Gammaproteobacteria (Fig. 5; all 19 samples shown in Fig. S5). One Cupriavidus ASV accounted for up to $31 \%$ of the total relative abundance at the onset of the first bloom and this ASV revealed an oscillating pattern throughout the season. During the peak of the spring bloom, the particle-attached prokaryotic community was dominated by ASVs belonging to Nitrincolaceae $(\approx 46 \%)$, SAR92 $(\approx 12 \%)$, Aurantivirga $(\approx 15 \%)$ and Ulvibacter $(\approx 13 \%)$. During the spring to summer transition, abundant ASVs belonged to Nitrincolaceae $(\approx 37 \%)$, Pseudomonas ( $\approx 18 \%$ ), the Rhodobacterales Ascidiaceihabitans $(\approx 3 \%)$, and the Flavobacterales Ulvibacter ( $\approx$ 5\%). The SAR11, SUP05, Amylibacter and Planktomarina 
ASVs determined for the free-living fraction were also present in the attached fraction, but their relative abundances were substantially lower $(<5 \%$ at each time point).

Prokaryotic diversity indices showed a distinct seasonal pattern in both the free-living and the particle-attached community (Fig. S6). The Shannon index, calculated with all ASVs, was similar for the two fractions at most time points. Shannon diversity of the free-living community was highest prior to the first bloom and rapidly decreased during the decline of the bloom. Thereafter, this index steadily increased over time to reach a value in late summer similar to the one determined in early spring.

\section{Associations between prokaryotic taxa and diatom species}

To investigate potential associations, we performed network analysis between diatoms and free-living and particle-attached prokaryotic taxa (each $\geq 1 \%$ of total abundance in at least one sample), based on 12 equally distant time points (Fig. 6). The network shows all detected correlations with the minimum absolute Spearman rho $>0.77(\mathrm{P} \leq 0.05$ and $\mathrm{Q} \leq 0.05)$. Our analysis revealed two groups of diatoms with different correlation patterns. One group was composed of diatoms with higher relative abundances during the spring bloom, such as Chaetoceros spp., Thalassionema nitzschioides and Thalassiosira antarctica, and these diatoms had overall only a few positive and mostly negative correlations with prokaryotic ASVs. Another group was composed of diatoms that were more abundant during summer, including the second bloom, and these diatoms had numerous positive correlations with ASVs. 
Examples are Guinardia cylindrus and Corethron inerme that had the highest number of positive correlations (in total 15 and 11, respectively) with ASVs in the free-living and particle-attached fractions.

A subset of ASVs, comprised of 8 free-living and 7 particle-attached ASVs, revealed opposite correlations with diatoms being more abundant in spring and summer. Several ASVs in the free-living fraction had 1-2 week time-lagged positive associations with diatoms abundant during the second bloom. Examples are ASVs belonging to SAR86, Kordiimonadales, Flavobacteriales NS9 and Formosa. On the contrary, ASVs showing positive correlations with patterns being ahead of time with respect to those of the associated diatoms were more abundant in the particle-attached fraction. These time-delayed correlations were detectable for ASVs belonging to Cryomorphaceae, to Rhodobacterales Ascidiaceihabitans, Magnetospira and Sphingomonas.

\section{Discussion}

Our observations obtained by a remote access sampler provide the first description of seasonal shifts in the microbial community composition in the open Southern Ocean. The high-resolution sampling frequency allows us to discuss the temporal patterns of 9 abundant prokaryotic taxa that account together for $36-77 \%$ of relative abundance throughout the season. The investigation of two successive phytoplankton blooms, each dominated by distinct diatom assemblages further provides a novel perspective on the links between 
heterotrophic microbes and phytoplankton. In combination with concurrent and previous observations, our data shed light on the ecology of microbes in an ocean region, where the trace element iron governs biogeochemical processes.

Seasonal phytoplankton dynamics and the bulk prokaryotic response

The spring and summer blooms differ in several aspects, with potential consequences on the associated heterotrophic microbial communities. The spring bloom is initiated by the stratification of the water column (Pellichero et al., 2020), allowing phytoplankton to grow on the large winter stock of major inorganic nutrients and iron (Blain et al., 2007). This bloom started in early November and extended over roughly 1 month. It was dominated by small (< $25 \mu \mathrm{m}$ ), fast growing diatom species such as Chaetoceros spp., Thalassionema nitzschioides, Thalassiosira spp. and small centric spp.. The second bloom was dominated by diatoms able to grow on low silicic acid concentrations and likely using $\mathrm{NH}_{4}{ }^{+}$as a major source of nitrogen. The duration of this bloom was overall shorter (2 weeks) and had its peak in early January. Large (> $25 \mu \mathrm{m}$ ), slow growing diatoms, such as Corethron inerme, Guinardia cylindrus, Thalassiothrix antarctica, and Rhizosolenia spp. were major contributors. The timing and magnitude of the blooms above the Kerguelen plateau varies inter-annually, and 10-year mean satellite-based Chl $a$ concentrations are $1 \mu \mathrm{g} \mathrm{L}^{-1}$ and $1.3 \mu \mathrm{g} \mathrm{L}{ }^{-1}$ for the first and the second bloom, respectively (Fig. S7).

Previous short-term investigations have shown that heterotrophic prokaryotes markedly respond to all phases of the Kerguelen bloom in terms of abundance and biomass production (Obernosterer et al., 2008, Christaki et al., 2014, Christaki et al., in revision). 
Prokaryotic abundances in surface waters at our study site range from $3.66 \times 10^{8}$ cells $\mathrm{L}^{-1}$ in mid October, to $4.48 \times 10^{8}$ cells $\mathrm{L}^{-1}$ in mid January and $5.8510^{8}$ cells $\mathrm{L}^{-1}$ in mid February and they can reach up to $11.8 \times 10^{8}$ cells $\mathrm{L}^{-1}$ in March (Table S3). The majority of prokaryotes (range 76 to $96 \%)$ is present in the free-living fraction $(<0.8 \mu \mathrm{m}$ size fraction) during these time periods (Table S3). Grazing by heterotrophic nanoflagellates is the dominant loss process of prokaryotes in early spring and late summer, and viral induced mortality is high in summer (Christaki et al. under revision).

Spring bloom prokaryotes

The peak of the spring phytoplankton bloom was accompanied by a marked increase in the relative abundance of Cellvibrionales SAR92 and the Flavobacteriales Aurantivirga. These taxa appear to be among the most rapid responders to the accumulation of diatom biomass, accounting together for up to $19 \%$ of total relative abundance (Fig. 7a). Their parallel increase and similar contribution to abundance indicate a high degree of niche specialization on the utilization of different diatom-derived substrates for growth (Xing et al., 2015; Krüger et al., 2019). Previous MICRO-CARD-FISH data revealed that SAR92 was an abundant and active member of the microbial community during the peak and decline of the Kerguelen spring bloom (Obernosterer et al., 2011). SAR92 and members of Flavobacteriaceae dominated gene abundance and expression of several glycoside hydrolase families during a spring bloom in the coastal North Sea (Teeling et al., 2012) and members of Flavobacteriaceae possess large and efficient polysaccharide uptake loci (PULs) (Kappelmann et al., 2019). MAGs belonging to Aurantivirga and the closely related Polaribacter had among the highest numbers of PULs and 
the most diverse substrate spectra for glycan degradation in coastal North Sea microbial communities (Krüger et al., 2019). The temporal pattern of SAR92 and Aurantivirga further suggests these taxa to be competitive in the utilization of phytoplankton-derived DOM under conditions when the access to iron is constrained due to the competition with small diatoms (Fourquez et al., 2015; Fourquez et et al., 2020). Using MICRO-CARD-FISH and ${ }^{55} \mathrm{Fe}$, Gammaproteobacteria and FCB dominated iron uptake in spring (Fourquez et al., 2016). Cellvibrionaceae (SAR92) and Flavobacteriaceae contributed each 10\% to $15 \%$ to total prokaryotic siderophore-bound iron uptake gene expression, while the contribution of Nitrincolaceae (formerly Oceanospirillaceae), a bacterial group that appeared later in the season (see below) was lower (5\%) (Debeljak et al., 2019). Collectively, these observations illustrate the metabolic potential of these groups for the rapid utilization of major compounds comprised in diatom-derived DOM coupled to efficient iron uptake strategies.

Prokaryotes during the transition from spring to summer

The most pronounced shift in the microbial community composition occurred during the decline of the spring bloom. A few taxa were present at high relative abundances, reflected in a decrease in the overall microbial diversity (Fig. S6). The Flavobacteriaceae Polaribacter and taxa belonging to Nitrincolaceae revealed peaks shortly after the bloom decline, accounting together for $40 \%$ of relative abundance (Fig. $7 \mathrm{~b}$ and 8 ). The short-term ‘feast and famine’- dynamics of Polaribacter and Nitrincolaceae are likely a consequence of the rapid utilization of the enhanced availability of phytoplankton-derived organic matter under less competitive conditions for iron with phytoplankton. Members of the well-studied 
Polaribacter spp. are among the first to respond in incubation experiments at low temperatures amended with diatom-derived DOM (Luria et al., 2017; Tada et al., 2017; Dadaglio et al., 2018) or specific substrates such as N-acetyl-glucose-amine (Dinasquet et al., 2017). Amylibacter (formerly NAC11-7 lineage) was the first abundant Rhodobacteraceae in our seasonal succession (Fig. 7b), followed by Planktomarina (RCA cluster)(Fig. S8). These Rhodobacteraceae members have a broad spectrum of substrates that are overall less complex, including sulfur compounds, carbohydrates and amino acids (Hahnke et al., 2013; Voget et al., 2015; Moran and Durham, 2019). Their increased contribution could therefore reflect changes in the DOM composition over time. In addition, RCA representatives from Antarctic waters have distinct iron uptake and metabolism strategies (Sun et al., 2017), in line with observations from early spring when Rhodobacteraceae accounted for 5-10\% of total $\mathrm{Fe}^{2+}$ and $\mathrm{Fe}^{3+}$ uptake transcripts (Debeljak et al., 2019).

Prokaryotic taxa with potential implication in the nitrogen cycle

Besides the bloom-associated changes in organic matter supply, inorganic nitrogen speciesrevealed pronounced seasonal dynamics (Fig. 8a). Phytoplankton growth resulted in the drawdown of nitrate in early spring, paralleled by an increase in ammonium due to organic matter mineralization by zooplankton and heterotrophic microbes. It was interesting to note that nitrite concentrations increased during the spring bloom and remained elevated throughout the season. The production of nitrite is an intermediate step of nitrification (oxidation of nitrogen from oxidation degree III NH$/ \mathrm{NH}_{4}{ }^{+}$to oxidation degree $\mathrm{V} \mathrm{NO}_{3}{ }^{-}$) (Kuypers et al., 2018). This transformation requires a number of oxidation steps that are 
mediated by different microorganisms. Our observations reveal successive peaks in Pseudomonadaceae, followed by Nitrincolaceae concurrent to changes in inorganic nitrogen species (Fig. 8b, c; Fig. S9 illustrates the temporal pattern in the particle-attached fraction).

The increase in the relative abundance of Pseudomonadaceae was concomitant to the increase in $\mathrm{NH}_{4}{ }^{+}$, which could be the substrate for their ammonia-oxidizing activity (Stein and Klotz, 2016; Xu et al., 2017; Huang et al., 2019). Among the well-known ammonia oxidizers, Nitrosopumilus and Nitrospina were present at low relative abundances during the first two time points ( $<4 \%$ of total abundance), and they accounted for $<1 \%$ during the remaining season. Pseudomonadaceae and Nitrincolaceae contain genes for nitrite oxidoreductase (NXR) (Mori et al., 2019), mediating the transformation from nitrite to nitrate. Genes for nitrite reductase (NIR), nitric oxide reductase (NOR) and nitrous oxide reductase (NOS) are further present in Nitrincolaceae (Mori et al., 2019) indicating their potential to reduce nitrite to nitrous oxide $\left(\mathrm{N}_{2} \mathrm{O}\right)$ and dinitrogen $\left(\mathrm{N}_{2}\right)$.

These processes were previously reported in the Kerguelen region in spring (Farías et al., 2015). Aerobic heterotrophic microbes can couple nitrite oxidation to energy conservation, while relying on organic matter for growth (Kuypers et al., 2018). Nitrification processes are associated with high iron requirements, which appear to be met by both the iron supply (Blain et al., 2007; Sarthou et al., 2008) and the metabolic capability for the uptake of $\mathrm{Fe}^{3+}$ and siderophore-bound iron (Debeljak et al., 2019). Based on seasonal changes in nitrate concentrations, uptake rates, and the decoupling between $\mathrm{N}$ and $\mathrm{O}$ isotopes, Fripiat and collaborators (2015) have suggested that nitrification in the mixed layer could explain the 
maintenance of high nitrate concentrations in the bloom throughout the season. Our observations add support to this explanation revealing the main microbial taxa (Pseudomonadaceae and Nitrincolaceae) associated to this unresolved biogeochemical issue in iron fertilized waters of the Southern Ocean.

Dominant prokaryotes outside the bloom periods

ASVs belonging to SAR11-clade Ia and Thioglobaceae SUP05 were major contributors at the onset of the spring bloom and in late summer, accounting together for up to 30\% of the microbial community (Fig. 7c). Using MICRO-CARD-FISH, SAR11 had substantial contributions to bulk prokaryotic abundance and biomass production in the study region in early spring (Fourquez et al., 2016), decreasing to $<10 \%$ during the declining phase of the spring phytoplankton bloom (Obernosterer et al., 2011), confirming our sequencing data. SAR11 were shown to be abundant community members during winter in the Southern Ocean based on a modelling approach (Ladau et al., 2013) and in situ observations in waters off Antarctica (Williams et al., 2013; Luria et al., 2016). The comparison of two metagenomes, collected off the Western Antarctic Peninsula (WAP; Palmer Station) in winter and summer, respectively, revealed a seasonal pattern for SUP05 similar to the one of the present study (Grzymski et al., 2012). The nutritional characteristics of these groups, such as the oligotrophic-type life style of SAR11 (Giovannoni, 2017) aided by proteorhodopsin under carbon-limited conditions (Steindler et al., 2011), and the potential to couple inorganic carbon fixation to the oxidation of reduced sulfur compounds of SUP05 clade (Walsh et al., 2009; Swan et al., 2011), present advantageous metabolic strategies during the low productive 
season. A gene-specific metatranscriptomics approach carried out at the same study site in early spring revealed that $\mathrm{Fe}^{3+}$ transcripts belonging to Pelagibacteraceae accounted for $<1 \%$ of alphaproteobacterial transcripts, and no Thioglobaceae (SUP05) transcripts were detectable for any of the iron uptake pathways (Debeljak et al., 2019). Reduced cellular iron requirements or efficient uptake and utilization of iron could be possible strategies by SAR11 and SUP05, which is in line with the suggested streamlining for both organisms (Rogge et al., 2017).

Contrasting patterns of prokaryote-diatom associations in spring vs summer

In contrast to the pronounced shifts of heterotrophic prokaryotic taxa over the course of the spring phytoplankton bloom, changes were subtler during the consecutive summer bloom. The growth of microbial taxa adapted to the degradation of diatom-derived DOM during spring is likely the main reason for a less marked transition. Distinct diatom communities contributed to the two blooms, raising the question of the specificity of the prokaryote-diatom associations. The correlations we obtained between a given diatom species and prokaryotic taxa and vise versa were multiple, suggesting that the majority of these associations reflect non-specific interactions. On the one hand, phytoplankton was shown to explain changes in heterotrophic prokaryotic communities better than environmental parameters on temporal and spatial scales (Lima-Mendez et al., 2015; Needham and Fuhrman, 2016; Liu et al., 2019). On the other hand, the production of common biologically labile substrates is in part independent of the phytoplankton assemblage and was suggested to explain recurrent patterns in prokaryotic community composition (Teeling et al., 2016). These 
observations point to the importance of a better understanding of the types of interactions and on the scale over which they control microbial community composition and biogeochemical fluxes (Landa et al., 2016).

An interesting observation in the present study was the contrasting pattern of associations in spring and summer. Prokaryotic taxa had only a few positive associations with diatom species dominating the spring bloom, while they were numerous with representative summer diatoms. To explain this observation, we provide in the following a scenario, based on phytoplankton-prokaryote interactions under seasonally varying environmental conditions in the Southern Ocean. In spring, small, fast-growing diatoms build up phytoplankton biomass, thereby rapidly depleting the winter stock of iron (Blain et al., 2007). The availability of diatom-derived organic carbon to heterotrophic prokaryotes controls their access to iron (Fourquez et al., 2015). In this setting, competition dominates over interaction, which could lead to a low number of positive associations between diatoms and heterotrophic microbes. In summer, many dominating diatoms are characterized by slow growth and large cell sizes ( $25 \mu \mathrm{m}$ to up to $1 \mathrm{~mm}$ ). The resulting larger phycosphere presents a micro-habitat with enhanced concentrations of organic matter released by phytoplankton (Seymour et al., 2017). Growth in the vicinity of the cells provide heterotrophic prokaryotes with an ecological advantage (Simon et al., 2002; Grossart et al., 2003) and allows for a variety of symbiotic relationships based on the exchange of metabolites, including iron (Amin et al., 2012). In summer, phytoplankton rely on regenerated sources of iron (Blain et al., 2008; Sarthou et al., 2008; Tagliabue et al., 2014), and recycling of iron by heterotrophic microbes contribute to this pool through the 'microbial ferrous wheel' (Kirchman, 1996). This 
environmental context could be more favorable for positive interactions between autotrophic and heterotrophic microbes.

Several of the microbial taxa identified at different phytoplankton bloom stages at our study site are known to play similar roles in other marine environments. This suggests adaption of closely related members of the same taxa to certain environmental constraints while maintaining distinct ecological niches. The year-round low temperatures and the growth-limiting concentrations of iron are among the specific features of the Southern Ocean. Identifying microbial community members implicated in a given biogeochemical process and describing their temporal dynamics in remote oceans is a challenging objective. The combination of automated instrumentation represents a powerful strategy to carry out the required sampling and observation at sites with limited access. These tools are crucial for inventories of microbial communities and for any predictions of the possible changes in microbial diversity and associated biogeochemical fluxes in response to global environmental change.

\section{Experimental procedures}

\section{Study site and sampling strategy}

Our study site is located above the central Kerguelen plateau $\left(50.63^{\circ} \mathrm{S}, 72.06^{\circ} \mathrm{E}\right.$; overall depth $527 \mathrm{~m}$ ) in the Indian Sector of the Southern Ocean (Fig. 1). Seawater was collected with a Remote Access Sampler (RAS-500®, Mac Lane) from 25 October 2016 to 24 February 2017. 
The mooring of the RAS was equipped with a CTD sensor continuously recording conductivity and temperature (Seabird SBE19+). The RAS was positioned at $\sim 40 \mathrm{~m}$ to assure sample collection in the mixed layer throughout the season. The surface mixed layer was as deep as $150 \mathrm{~m}$ in late October, it decreased to $100 \mathrm{~m}$ during November and remained at roughly $70 \mathrm{~m}$ during the remaining observation period (Pellichero et al., 2020). The RAS can collect up to 48 seawater samples, each of $500 \mathrm{~mL}$, in an autonomous manner. For the present study, 3 samples were collected at 12 evenly spaced time points (11 days) and 2 samples were collected at 6 intermediate time points (18 time points in total): 1 sample was in situ prefiltered through an $0.8 \mu \mathrm{m}$ polycarbonate (PC, $47 \mathrm{~mm}$ diameter, Nuclepore, Whatman, Sigma Aldrich, St. Luis, MO) filter, and 2 samples remained unfiltered. The $0.8 \mu \mathrm{m}$-filtered samples served for inorganic nutrient analyses and the unfiltered samples were used for the determination of diatom and prokaryotic community composition (Table S1).

Fixatives were added to the sample bags prior to deployment. Mercuric chloride ( $\mathrm{HgCl}_{2}, 2 \%$ final conc.) was used as fixative for the $0.8 \mu \mathrm{m}$-filtered samples and for one of the unfiltered samples, and glutaraldehyde (1\% final conc.) was used as fixative for the other unfiltered sample. The functioning of the RAS is described in detail in the manufacturers guidelines (https://mclanelabs.com/ras-manuals/). Briefly, each sampling bag is contained in a plexiglass cylinder, surrounded by Milli-Q water prior to deployment. At the time of sampling, the Milli-Q water is pumped out of the sampling device, and replaced by the respective volume of seawater that enters the bags and mixes with the fixative. This allows seawater to enter the sampling bags without passing through a pump. Following the 4-months deployment, the seawater of each sample bag was transferred to $500 \mathrm{~mL}$ PC bottles for transport to the 
home laboratory. An additional sample was taken on 6 April 2017 during the voyage of the recovery of the RAS. The seawater was collected at about $5 \mathrm{~m}$ depth using the underway water supply system and fixed with glutaraldehyde until return to the home lab.

For microbial diversity analyses, $200 \mathrm{~mL}$ of unfiltered seawater were sequentially filtered through $0.8 \mu \mathrm{m}$ and $0.2 \mu \mathrm{m}$ PC filters (Nuclepore). The filters were kept at $-80^{\circ} \mathrm{C}$ until DNA extraction. The identification, enumeration and biomass determination of the diatom assemblages were done on $200 \mathrm{~mL}$ of unfiltered seawater. Microscopic observations were carried out in an Utermöhl counting chamber (24 h, dark) using an inverted microscope with phase contrast (Olympus IX70) with 400× magnification as described in Rembauville et al. (2017). The concentrations of inorganic nutrients (nitrate, nitrite, silicic acid and ammonium) were determined in the home lab according to standard protocols (Blain et al., 2014).

\section{Effect of fixatives on DNA extraction and microbial diversity}

To evaluate the potential effect of $\mathrm{HgCl}_{2}$ and glutaraldehyde, used as fixatives in the RAS, on DNA extraction and microbial diversity analyses, we performed two tests series using seawater from the coastal Mediterranean Sea (Bay of Banyuls sur mer, France). The first objective was to test whether sufficient amounts of DNA could be extracted from $\mathrm{HgCl}_{2}$ or glutaraldehyde fixed $200 \mathrm{~mL}$ samples stored for 4 months at $4^{\circ} \mathrm{C}$, corresponding to the maximum temperature at our study site in the Southern Ocean. We therefore compared three DNA extraction kits, i.e. Quick-DNA Fungal/ Bacterial Miniprep Kit (ZYMO research, 
California, USA), AllPrep DNA/ RNA Kit (Qiagen, Hilden, Germany) and DNeasy

PowerWater Kit (Qiagen, Hilden, Germany) (Table S4). Surface seawater was collected with three 2-L PC carboys, each containing 1 L. One liter of non-fixed seawater was treated with a standard protocol, thereafter referred to as control. Therefore, $200 \mathrm{~mL}$ sub-samples (in 4 replicates) were immediately sequentially filtered through $0.8 \mu \mathrm{m}$ and $0.2 \mu \mathrm{m}$ PC filters and stored at $-80^{\circ} \mathrm{C}$. Seawater in the other two PC carboys was fixed either with $\mathrm{HgCl}_{2}$ (2\% final conc.) or glutaraldehyde ( $1 \%$ final conc.) and stored at $4^{\circ} \mathrm{C}$ in the dark for 4 months. The fixed samples were then filtered (200 mL, in 4 replicates) through $0.8 \mu \mathrm{m}$ and $0.2 \mu \mathrm{m}$ PC filters and stored at $-80^{\circ} \mathrm{C}$ until DNA extraction. For each treatment (control, $+\mathrm{HgCl}_{2}$, +glutaraldehyde) one filter was sacrificed for the DNA extraction with a given kit. After comparison of the results, the DNeasy PowerWater Kit was chosen for further work (Table S4). For a first evaluation of the quality of the sequences, we only considered 3 samples (< $0.8 \mu \mathrm{m}$ fraction of the control, $+\mathrm{HgCl}_{2}$, + glutaraldehyde treatments). In the second test series, the same sampling, fixation and storage protocol as described above was applied. However, using only one DNA extraction kit (DNeasy PowerWater Kit) allowed us to obtain DNA and sequences from biological triplicates of each treatment.

Because of the low number of sequences (5 181) and sequencing contamination, 2 samples were removed from the second series, resulting in 3 and 16 samples in total for the first and the second test series, respectively. The rarefied number of sequences was 17943 for the first and 9903 for the second test series (data analysis is described below). Results from the first test revealed high similarity between the 3 samples (Fig. S10). The results from the second test overall confirmed these results. The composition of prokaryotic communities of samples 
fixed with $\mathrm{HgCl}_{2}$ were not significantly different from the control samples, both in the freeliving and the particle-attached fractions (sigclustTest, $\mathrm{P}>0.05)($ Fig. S10). Prokaryotic community composition in samples fixed with glutaraldehyde was not significantly different from control samples in the free-living fraction (sigclustTest, $\mathrm{P}>0.05$ ), but this was not the case for the particle-attached fraction (sigclustTest, $\mathrm{P}<0.05$ ). We further compared the prokaryotic communities from samples collected by the RAS and fixed either with $\mathrm{HgCl}_{2}$ or glutaraldehyde (8 time points). No significant differences between fixatives were observed for any of the size fractions (sigclustTest, $\mathrm{P}>0.05$ ). According to these collective observations, we chose the samples fixed by $\mathrm{HgCl}_{2}$, with the exception of 2 dates (2017.02.13 and 2017.02.24) for which only glutaraldehyde fixed samples were available (Table S1).

\section{DNA extraction and sequencing preparation}

DNA was extracted from the $0.8 \mu \mathrm{m}$ and $0.2 \mu \mathrm{m}$ filters using the DNeasy PowerWater Kit (Qiagen, Hilden, Germany) following the manufacturer's guidelines with a few modifications. Each filter was cut into small pieces with a sterile scalpel and then transferred to the $5 \mathrm{ml}$ PowerWater DNA bead tube. Each bead tube was heated at $65^{\circ} \mathrm{C}$ for $10 \mathrm{~min}$ to aid the lysis of cells after adding solution PW1. The tube was horizontally placed on a vortex mixer (VortexGenie 2, USA Scientific, Florida, USA) and vortexed at maximum speed for $10 \mathrm{~min}$.

Following the protocol, DNA extracts were obtained and ready for amplification. The V4-V5 region of the 16S rRNA gene from both fractions was amplified with the primer sets 515F-Y (5'-GTGYCAGCMGCCGCGGTAA) and 926-R (5'-CCGYCAATTYMTTTRAGTTT) as 
described in Parada et al. (2016) with a modification to the PCR amplification step. Triplicate $20 \mu \mathrm{L}$ reaction mixtures contained $2 \mu \mathrm{g}$ DNA, $5 \mu$ KAPA2G Fast HotStart ReadyMix, $0.2 \mu \mathrm{M}$ forward primer and $0.2 \mu \mathrm{M}$ reverse primer. Cycling reaction started with a 3 min heating step at $95^{\circ} \mathrm{C}$ followed by 30 cycles of $95^{\circ} \mathrm{C}$ for $45 \mathrm{~s}, 50^{\circ} \mathrm{C}$ for $45 \mathrm{~s}, 68^{\circ} \mathrm{C}$ for $90 \mathrm{~s}$, and a final extension of $68^{\circ} \mathrm{C}$ for $5 \mathrm{~min}$. The presence of amplification products was confirmed by $1 \%$ agarose electrophoresis and triplicate reactions were pooled. The pooled PCR amplicons were purified using Sephadex G-50 Superfine resin (GE Healthcare Bio-Sciences, New Jersey, USA) following the protocol. The purification step aims to desalt the samples and eliminate unincorporated nucleotides and excess PCR primers. 16S rRNA gene amplicons were sequenced with Illumina MiSeq $2 \times 250$ bp chemistry on one flow-cell at GeT-PlaGe platform (Toulouse, France). A mock community DNA (LGC standards, UK) was used as a standard for subsequent analyses and considered as a DNA sample for all treatments.

\section{Data analysis}

All samples from the sequencing run were demultiplexed by GeT-PlaGe and barcodes were trimmed off. Processing of sequences was performed using the DADA2 pipeline (version 1.10) (Callahan et al., 2016) in $\mathrm{R}$ (version 3.4.2) with following parameters: $\operatorname{trimLeft}=\mathrm{c}(19$, 20), truncLen $=c(240,200), \max N=0, \operatorname{maxEE}=c(2,2)$, truncQ=2. Briefly, the pipeline combines the following steps: filtering and trimming, dereplication, sample inference, chimera identification, and merging of paired-end reads. It provides exact amplicon sequence variants (ASVs) from sequencing data with one nucleotide difference instead of building 
operational taxonomic units (OTUs) based on sequence similarity. ASVs were assigned against SILVA release 132 database (Quast et al., 2012). Singletons and sequences assigned to chloroplast and mitochondria were removed prior to subsequent analyses.

\section{Statistical analyses}

All statistical analyses were performed using R 3.4.2 version. The ASV and taxa tables were combined into one object using phyloseq R package (McMurdie and Holmes, 2013). Data were Hellinger transformed prior to the analyses based on Bray-Curtis dissimilarity (Legendre and Gallagher, 2001). Bray-Curtis dissimilarity matrices were generated via vegdist function (Oksanen et al., 2017). The significant differences between pairwise RAS test sub-samples were tested using the function sigclustTest within the R package sigclust (Liu et al., 2008; Huang et al., 2015). Nonmetric dimensional scaling (NMDS) ordinations were generated based on Bray-Curtis dissimilarity using monoMDS function in the package vegan (Oksanen et al., 2017). Analysis of similarity (ANOSIM) was performed to test significant differences between fractions in microbial communities of the RAS samples. Sequences alignment was carried out using MAFFT algorithm web services by defaults (Katoh et al., 2019). The phylogenetic tree was constructed using PhyML 3.0 online programs based on maximum likelihood method and 100 bootstraps with HKY85 substitution model (Guindon and Gascuel, 2003). The tree was visualized with SeaView version 4.7 and saved as rooted tree. Heatmaps were generated using heatmap3 package and rows were reordered corresponding to phylogenetic tree. The richness and shannon indexes were examined using 
estimate_richness, and evenness index was calculated by “Shannon/log(richness)". Base package and the package ggplot2 were used to plot graphs, except Figure 1 using 2.7 matplot library, and Figures 2, 7 and 8 using Sigma Plot 12.5 software.

\section{Network construction}

Extended local similarity analysis (eLSA) was applied to determine the potential correlations between prokaryotic taxa and diatoms, with time being taken into consideration. Correlations of co-occurrence at each time point and correlations that may be lagged in time can be found using eLSA with the focus on the "coexistence" of microbial taxa (Ruan et al., 2006; Xia et al., 2011). For this analysis, 12 time points each separated by 11 days were used (Table S1). The prokaryotic ASVs and diatom species, each with relative abundances $\geq 1 \%$ in at least one sample in each data set (diatom community composition, free-living prokaryotes and particleattached prokaryotes) were included. Time delayed (D) positive and negative correlations with the setting of 0 to 2 units were examined, where 1 unit equals 11 days. The maximal delay unit was determined according to microbial growth rates and our interest in delayed correlations of up to three weeks. Growth rates for prokaryotes range between $0.02-0.47 \mathrm{~d}^{-1}$ in early spring and summer at our study site (Obernosterer et al.,2008; Landa et al., 2016) and

growth rates of major diatom species in the Southern Ocean vary between 0.24 to $0.62 \mathrm{~d}^{-1}$ (Timmermans et al., 2004). The network was visualized using Cytoscape (3.7.0) software platform (Shannon, 2003). 


\section{Accession numbers}

Demultiplexed sequence files are available in NCBI under accession number PRJNA613169.

\section{Conflict of Interest}

The authors declare that they have no conflict of interest.

\section{Acknowledgements}

We thank the team of the Technical Division of the Institute of the Sciences of the Universe (DT-INSU) for the design and the construction of the mooring for the RAS. We thank the captains and the crews of the $R / V$ Marion Dufresne for their support during the deployment and the recovery of the RAS. The project SOCLIM (Southern Ocean and Climate) was supported by the Climate Initiative of the BNP Paribas foundation, the French Polar Institute (Institut Polaire Paul Emile Victor), and the French program LEFE-CYBER of the CNRSINSU. We thank the GenoToul Bioinformatics platform (http://bioinfo.genotoul.fr/) for providing computing resources. We appreciate valuable comments on this data set provided by Angel Rain, Fengzhu Sun, Pavla Debeljak, and Nyree West. Suggestions from two anonymous reviewers helped improve a previous version of the manuscript. This work is part of the PhD thesis of Y.L. supported by the China Scholarship Council (CSC; NO. 201606330072). 


\section{References}

Alonso-Saez, L. and Gasol, J.M. (2007) Seasonal variations in the contributions of different bacterial groups to the uptake of low-molecular-weight compounds in northwestern Mediterranean coastal waters. Appl Environ Microbiol 73: 3528-3535.

Amin, S.A., Parker, M.S., and Armbrust, E.V. (2012) Interactions between diatoms and bacteria. Microbiol Mol Biol Rev 76: 667-684.

Blain, S., Capparos, J., Guéneuguès, A., Obernosterer, I., and Oriol, L. (2014) Distributions and stoichiometry of dissolved nitrogen and phosphorus in the iron fertilized region near Kerguelen (Southern Ocean). Biogeosci Discuss 11: 9949-9977.

Blain, S., Quéguiner, B., Armand, L., Belviso, S., Bombled, B., Bopp, L., et al. (2007) Effect of natural iron fertilization on carbon sequestration in the Southern Ocean. Nature 446: 1070-1074.

Blain, S., Sarthou, G., and Laan, P. (2008) Distribution of dissolved iron during the natural iron-fertilization experiment KEOPS (Kerguelen Plateau, Southern Ocean). Deep-Sea Res PT II. 55: 594-605.

Buchan, A., LeCleir, G.R., Gulvik, C.A., and González, J.M. (2014) Master recyclers: features and functions of bacteria associated with phytoplankton blooms. Nat Rev Microbiol 12: 686-698. 
Bunse, C. and Pinhassi, J. (2017) Marine Bacterioplankton Seasonal Succession Dynamics. Trends Microbiol 25: 494-505.

Buttigieg, P.L., Fadeev, E., Bienhold, C., Hehemann, L., Offre, P., and Boetius, A. (2018) Marine microbes in 4D - using time series observation to assess the dynamics of the ocean microbiome and its links to ocean health. Curr Opin Microbiol 43: 169-185.

Callahan, B.J., McMurdie, P.J., Rosen, M.J., Han, A.W., Johnson, A.J.A., and Holmes, S.P. (2016) DADA2: High-resolution sample inference from Illumina amplicon data. Nat Methods 13: 581-583.

Chafee, M., Fernàndez-Guerra, A., Buttigieg, P.L., Gerdts, G., Eren, A.M., Teeling, H., and Amann, R.I. (2018) Recurrent patterns of microdiversity in a temperate coastal marine environment. ISME J 12: 237-252.

Dadaglio, L., Dinasquet, J., Obernosterer, I., and Joux, F. (2018) Differential responses of bacteria to diatom-derived dissolved organic matter in the Arctic Ocean. Aquat Microb Ecol 82: 59-72.

Debeljak, P., Toulza, E., Beier, S., Blain, S., and Obernosterer, I. (2019) Microbial iron metabolism as revealed by gene expression profiles in contrasted Southern Ocean regimes. Environ Microbiol 21: 2360-2374.

Dinasquet, J., Richert, I., Logares, R., Yager, P., Bertilsson, S., and Riemann, L. (2017) Mixing of water masses caused by a drifting iceberg affects bacterial activity, 
community composition and substrate utilization capability in the Southern Ocean: iceberg influence on bacterioplankton. Environ Microbiol 19: 2453-2467.

Farías, L., Florez-Leiva, L., Besoain, V., Sarthou, G., and Fernández, C. (2015) Dissolved greenhouse gases (nitrous oxide and methane) associated with the naturally ironfertilized Kerguelen region (KEOPS 2 cruise) in the Southern Ocean. Biogeosciences 12: $1925-1940$.

Fourquez, M., Beier, S., Jongmans, E., Hunter, R., and Obernosterer, I. (2016) Uptake of Leucine, Chitin, and Iron by Prokaryotic Groups during Spring Phytoplankton Blooms Induced by Natural Iron Fertilization off Kerguelen Island (Southern Ocean). Front Mar Sci 3: 256.

Fourquez, M., Bressac, M., Deppeler, S.L., Ellwood, M., Obernosterer, I., Trull, T.W., and Boyd, P.W. (2020) Microbial Competition in the Subpolar Southern Ocean: An Fe-C Co-limitation Experiment. Front Mar Sci 6: 1-15.

Fourquez, M., Obernosterer, I., Davies, D.M., Trull, T.W., and Blain, S. (2015) Microbial iron uptake in the naturally fertilized waters in the vicinity of the Kerguelen Islands: phytoplankton-bacteria interactions. Biogeosciences 12: 1893-1906.

Fripiat, F., Elskens, M., Trull, T.W., Blain, S., Cavagna, A.-J., Fernandez, C., et al. (2015) Significant mixed layer nitrification in a natural iron-fertilized bloom of the Southern Ocean: Nitrification in an iron-fertilized area. Global Biogeochem Cy 29: 1929-1943. 
Fuhrman, J.A., Cram, J.A., and Needham, D.M. (2015) Marine microbial community dynamics and their ecological interpretation. Nat Rev Microbiol 13: 133-146.

Fuhrman, J.A., Hewson, I., Schwalbach, M.S., Steele, J.A., Brown, M.V., and Naeem, S. (2006) Annually reoccurring bacterial communities are predictable from ocean conditions. Proc Natl Acad Sci USA 103: 13104-13109.

Ghiglione, J.F. and Murray, A.E. (2012) Pronounced summer to winter differences and higher wintertime richness in coastal Antarctic marine bacterioplankton: Temporal variation in Southern Ocean coastal bacterioplankton. Environ Microbiol 14: 617-629.

Gilbert, J.A., Steele, J.A., Caporaso, J.G., Steinbrück, L., Reeder, J., Temperton, B., et al. (2012) Defining seasonal marine microbial community dynamics. ISME J 6: 298-308.

Giovannoni, S.J. (2017) SAR11 Bacteria: The Most Abundant Plankton in the Oceans. Ann Rev Marine Sci 9: 231-255.

Giovannoni, S.J. and Vergin, K.L. (2012) Seasonality in ocean microbial communities. Science 335: 671-676.

Grossart, H., Hietanen, S., and Ploug, H. (2003) Microbial dynamics on diatom aggregates in Øresund, Denmark. Mar Ecol Prog Ser 249: 69-78.

Grzymski, J.J., Riesenfeld, C.S., Williams, T.J., Dussaq, A.M., Ducklow, H., Erickson, M., et al. (2012) A metagenomic assessment of winter and summer bacterioplankton from Antarctica Peninsula coastal surface waters. ISME J 6: 1901-1915. 
Guindon, S. and Gascuel, O. (2003) A simple, fast, and accurate algorithm to estimate large phylogenies by maximum likelihood. Syst Biol 52: 696-704.

Hahnke, S., Brock, N.L., Zell, C., Simon, M., Dickschat, J.S., and Brinkhoff, T. (2013) Physiological diversity of Roseobacter clade bacteria co-occurring during a phytoplankton bloom in the North Sea. Syst Appl Microbiol 36: 39-48.

Hanson, C.A., Fuhrman, J.A., Horner-Devine, M.C., and Martiny, J.B.H. (2012) Beyond biogeographic patterns: processes shaping the microbial landscape. Nat Rev Microbiol 10: 497-506.

Huang, H., Liu, Y., Yuan, M., and Marron, J.S. (2015) Statistical significance of clustering using soft thresholding. J Comput Graph Stat 24: 975-93.

Huang, X., Xu, Y., He, T., Jia, H., Feng, M., Xiang, S., et al. (2019) Ammonium transformed into nitrous oxide via nitric oxide by Pseudomonas putida Y-9 under aerobic conditions without hydroxylamine as intermediate. Bioresour Technol 277: 87-93.

Irion, S., Jardillier, L., Sassenhagen, I. and Christaki, U. (2020) Marked spatiotemporal variations in small phytoplankton structure in contrasted waters of the Southern Ocean (Kerguelen area). Limnology and Oceanography: 1-18.

Kappelmann, L., Krüger, K., Hehemann, J.-H., Harder, J., Markert, S., Unfried, F., et al. (2019) Polysaccharide utilization loci of North Sea Flavobacteriia as basis for using 
SusC/D-protein expression for predicting major phytoplankton glycans. ISME J 13: 76-91.

Katoh, K., Rozewicki, J., and Yamada, K.D. (2019) MAFFT online service: multiple sequence alignment, interactive sequence choice and visualization. Brief Bioinform 20: $1160-1166$.

Kirchman, D.L. (1996) Microbial ferrous wheel. Nature 383: 303-304.

Krüger, K., Chafee, M., Ben Francis, T., Glavina del Rio, T., Becher, D., Schweder, T., et al. (2019) In marine Bacteroidetes the bulk of glycan degradation during algae blooms is mediated by few clades using a restricted set of genes. ISME J 13: 2800-2816.

Kuypers, M.M.M., Marchant, H.K., and Kartal, B. (2018) The microbial nitrogen-cycling network. Nat Rev Microbiol 16: 263-276.

Ladau, J., Sharpton, T.J., Finucane, M.M., Jospin, G., Kembel, S.W., O’Dwyer, J., et al. (2013) Global marine bacterial diversity peaks at high latitudes in winter. ISME J 7: $1669-1677$.

Lambert, S., Tragin, M., Lozano, J.C., Ghiglione, J.F., Vaulot, D., Bouget, F.Y., and Galand, P.E. (2019) Rhythmicity of coastal marine picoeukaryotes, bacteria and archaea despite irregular environmental perturbations. ISME J 13: 388-401. 
Landa, M., Blain, S., Christaki, U., Monchy, S., and Obernosterer, I. (2016) Shifts in bacterial community composition associated with increased carbon cycling in a mosaic of phytoplankton blooms. ISME J 10: 39-50.

Lasbleiz, M., Leblanc, K., Armand, L.K., Christaki, U., Georges, C., Obernosterer, I., et al. (2016) Composition of diatom communities and their contribution to plankton biomass in the naturally iron-fertilized region of Kerguelen in the Southern Ocean. FEMS microbiology ecology, 92, p.fiw171.

Legendre, P. and Gallagher, E.D. (2001) Ecologically meaningful transformations for ordination of species data. Oecologia 129: 271-280.

Lima-Mendez, G., Faust, K., Henry, N., Decelle, J., Colin, S., Carcillo, F., et al. (2015) Determinants of community structure in the global plankton interactome. Science $\mathbf{3 4 8}$ : 1262073-1262073.

Lindh, M.V., Sjöstedt, J., Andersson, A.F., Baltar, F., Hugerth, L.W., Lundin, D., et al. (2015) Disentangling seasonal bacterioplankton population dynamics by high-frequency sampling: High-resolution temporal dynamics of marine bacteria. Environ Microbiol 17: 2459-2476.

Liu, Y., Debeljak, P., Rembauville, M., Blain, S., and Obernosterer, I. (2019) Diatoms shape the biogeography of heterotrophic prokaryotes in early spring in the Southern Ocean. Environ Microbiol 21: 1452-1465. 
Liu, Y., Hayes, D.N., Nobel, A., and Marron, J.S. (2008) Statistical significance of clustering for high-dimension, low-sample size data. J Am Stat Assoc 103: 1281-93.

Luria, C.M., Amaral-Zettler, L.A., Ducklow, H.W., Repeta, D.J., Rhyne, A.L., and Rich, J.J. (2017) Seasonal shifts in bacterial community responses to phytoplankton-derived dissolved organic matter in the Western Antarctic Peninsula. Front Microbiol 8: 2117.

Luria, C.M., Amaral-Zettler, L.A., Ducklow, H.W., and Rich, J.J. (2016) Seasonal succession of free-living bacterial communities in coastal waters of the Western Antarctic Peninsula. Front Microbiol 7: 1731.

McMurdie, P.J. and Holmes, S. (2013) phyloseq: An R package for reproducible interactive analysis and graphics of microbiome census data. PLoS ONE 8: e61217.

Moran, M.A. and Durham, B.P. (2019) Sulfur metabolites in the pelagic ocean. Nat Rev Microbiol 17: 665-678.

Moran, M.A., Kujawinski, E.B., Stubbins, A., Fatland, R., Aluwihare, L.I., Buchan, A., et al. (2016) Deciphering ocean carbon in a changing world. Proc Natl Acad Sci USA 113: 3143-3151.

Mori, J.F., Chen, L.-X., Jessen, G.L., Rudderham, S.B., McBeth, J.M., Lindsay, M.B.J., et al. (2019) Putative mixotrophic nitrifying-denitrifying Gammaproteobacteria implicated in nitrogen cycling within the ammonia/oxygen transition zone of an oil sands pit lake. Front Microbiol 10: 2435. 
Mühlenbruch, M., Grossart, H.-P., Eigemann, F., and Voss, M. (2018) Mini-review: Phytoplankton-derived polysaccharides in the marine environment and their interactions with heterotrophic bacteria: Phytoplankton-derived polysaccharides. Environ Microbiol 20: 2671-2685.

Needham, D.M. and Fuhrman, J.A. (2016) Pronounced daily succession of phytoplankton, archaea and bacteria following a spring bloom. Nat Microbiol 1: 1-7.

Obernosterer, I., Catala, P., Lebaron, P., and West, N.J. (2011) Distinct bacterial groups contribute to carbon cycling during a naturally iron fertilized phytoplankton bloom in the Southern Ocean. Limnol Oceanogr 56: 2391-2401.

Obernosterer, I., Christaki, U., Lefèvre, D., Catala, P., Van Wambeke, F., and Lebaron, P. (2008) Rapid bacterial mineralization of organic carbon produced during a phytoplankton bloom induced by natural iron fertilization in the Southern Ocean. Deep-Sea Res PT II 55: 777-789.

Offre, P., Spang, A., and Schleper, C. (2013) Archaea in biogeochemical cycles. Ann Rev Microbiol 67: 437-457.

Oksanen, J., Blanchet, F.G., Friendly, M., Kindt, R., Legendre, P., McGlinn, D., et al. (2017) vegan: Community ecology package.

Parada, A.E., Needham, D.M., and Fuhrman, J.A. (2016) Every base matters: assessing small subunit rRNA primers for marine microbiomes with mock communities, time series 
and global field samples: Primers for marine microbiome studies. Environ Microbiol 18: $1403-1414$.

Pellichero, V., Boutin, J., Claustre, H., Merlivat, L., Sallée, J.B. and Blain, S. Relaxation of wind stress drives the abrupt onset of biological carbon uptake in the Kerguelen bloom: a multisensor approach (2020). Geophys Res Lett doi.org/10.1029/2019GL085992

Quast, C., Pruesse, E., Yilmaz, P., Gerken, J., Schweer, T., Yarza, P., et al. (2012) The SILVA ribosomal RNA gene database project: improved data processing and webbased tools. Nucleic Acids Res 41: D590-D596.

Rembauville, M., Briggs, N., Ardyna, M., Uitz, J., Catala, P., Penkerc’h, C., et al. (2017) Plankton assemblage estimated with BGC-Argo floats in the Southern Ocean: Implications for seasonal successions and particle export: Plankton assemblage BGCARGO. J Geophys Res Oceans 122: 8278-8292.

Rigual-Hernández, A.S., Trull, T.W., Bray, S.G., and Armand, L.K. (2016) The fate of diatom valves in the Subantarctic and Polar Frontal Zones of the Southern Ocean: Sediment trap versus surface sediment assemblages. Palaeogeogr Palaeoclimatol Palaeoecol 457: 129-143.

Rogge, A., Vogts, A., Voss, M., Jürgens, K., Jost, G., and Labrenz, M. (2017) Success of chemolithoautotrophic SUP05 and Sulfurimonas GD17 cells in pelagic Baltic Sea redox zones is facilitated by their lifestyles as $K$ - and $r$-strategists: SUP05 and Sulfurimonas in sulfidic redox zones. Environ Microbiol 19: 2495-2506. 
Ruan, Q., Dutta, D., Schwalbach, M.S., Steele, J.A., Fuhrman, J.A., and Sun, F. (2006) Local similarity analysis reveals unique associations among marine bacterioplankton species and environmental factors. Bioinformatics 22: 2532-2538.

Sarthou, G., Vincent, D., Christaki, U., Obernosterer, I., Timmermans, K.R., and Brussaard, C.P.D. (2008) The fate of biogenic iron during a phytoplankton bloom induced by natural fertilisation: Impact of copepod grazing. Deep-Sea Res PT II 55: 734-751.

Seymour, J.R., Amin, S.A., Raina, J.-B., and Stocker, R. (2017) Zooming in on the phycosphere: the ecological interface for phytoplankton-bacteria relationships. Nat Microbiol 2: 17065.

Shannon, P. (2003) Cytoscape: A software environment for integrated models of biomolecular interaction networks. Genome Res 13: 2498-2504.

Simon, M., Grossart, H., Schweitzer, B., and Ploug, H. (2002) Microbial ecology of organic aggregates in aquatic ecosystems. Aquat Microb Ecol 28: 175-211.

Stein, L.Y. and Klotz, M.G. (2016) The nitrogen cycle. Curr Biol 26: R94-R98.

Steindler, L., Schwalbach, M.S., Smith, D.P., Chan, F., and Giovannoni, S.J. (2011) Energy starved candidatus Pelagibacter Ubique substitutes light-mediated ATP production for endogenous carbon respiration. PLOS ONE 6: e19725. 
Sun, Y., Zhang, Y., Hollibaugh, J.T., and Luo, H. (2017) Ecotype diversification of an abundant Roseobacter lineage: Roseobacter ecotypes and genomic differentiation. Environ Microbiol 19: 1625-1638.

Swan, B.K., Martinez-Garcia, M., Preston, C.M., Sczyrba, A., Woyke, T., Lamy, D., et al. (2011) Potential for chemolithoautotrophy among ubiquitous bacteria lineages in the dark ocean. Science 333: 1296-1300.

Tada, Y., Nakaya, R., Goto, S., Yamashita, Y., and Suzuki, K. (2017) Distinct bacterial community and diversity shifts after phytoplankton-derived dissolved organic matter addition in a coastal environment. J Exp Mar Biol Ecol 495: 119-128.

Tagliabue, A., Sallée, J.-B., Bowie, A.R., Lévy, M., Swart, S., and Boyd, P.W. (2014) Surface-water iron supplies in the Southern Ocean sustained by deep winter mixing. Nat Geosci 7: 314-320.

Teeling, H., Fuchs, B.M., Becher, D., Klockow, C., Gardebrecht, A., Bennke, C.M., et al. (2012) Substrate-controlled succession of marine bacterioplankton populations induced by a phytoplankton bloom. Science 336: 608-611.

Teeling, H., Fuchs, B.M., Bennke, C.M., Krüger, K., Chafee, M., Kappelmann, L., et al. (2016) Recurring patterns in bacterioplankton dynamics during coastal spring algae blooms. ELife 5: e11888. 
Timmermans, K.R., van der Wagt, B., and de Baar, H.J.W. (2004) Growth rates, halfsaturation constants, and silicate, nitrate, and phosphate depletion in relation to iron availability of four large, open-ocean diatoms from the Southern Ocean. Limnol Oceanogr 49: 2141-2151.

Voget, S., Wemheuer, B., Brinkhoff, T., Vollmers, J., Dietrich, S., Giebel, H.A., et al. (2015) Adaptation of an abundant Roseobacter RCA organism to pelagic systems revealed by genomic and transcriptomic analyses. ISME J 9: 371-384.

Walsh, D.A., Zaikova, E., Howes, C.G., Song, Y.C., Wright, J.J., Tringe, S.G., et al. (2009) Metagenome of a versatile chemolithoautotroph from expanding oceanic dead zones. Science 326: 578-582.

Williams, T.J., Long, E., Evans, F., DeMaere, M.Z., Lauro, F.M., Raftery, M.J., et al. (2012) A metaproteomic assessment of winter and summer bacterioplankton from Antarctic Peninsula coastal surface waters. ISME J 6: 1883-1900.

Williams, T.J., Wilkins, D., Long, E., Evans, F., DeMaere, M.Z., Raftery, M.J., et al. (2013) The role of planktonic Flavobacteria in processing algal organic matter in coastal East Antarctica revealed using metagenomics and metaproteomics. Environ Microbiol 15: $1302-1317$.

Xia, L.C., Steele, J.A., Cram, J.A., Cardon, Z.G., Simmons, S.L., Vallino, J.J., et al. (2011) Extended local similarity analysis (eLSA) of microbial community and other time series data with replicates. BMC Syst Biol 5: S15. 
Xing, P., Hahnke, R.L., Unfried, F., Markert, S., Huang, S., Barbeyron, T., et al. (2015) Niches of two polysaccharide-degrading Polaribacter isolates from the North Sea during a spring diatom bloom. ISME J 9: 1410-1422.

Xu, Y., He, T., Li, Z., Ye, Q., Chen, Y., Xie, E., and Zhang, X. (2017) Nitrogen removal characteristics of Pseudomonas putida Y-9 capable of heterotrophic nitrification and aerobic denitrification at low temperature. Biomed Res Int 2017: 1-7. 


\section{Figure Legends}

Fig. 1. Map of the region around Kerguelen Island and location of station A3 where the Remote Access Sampler (RAS) was deployed from 25 October 2016 to 24 February 2017.

Fig. 2. Temporal changes of Chlorophyll $a$ (green shaded area) and temperature (black circles) during the period of RAS deployment. Chlorophyll $a$ is derived from ocean color satellite data; globcolor products are available at Copernicus Marine Service (http://marine.copernicus.eu). Sampling dates of prokaryotic community composition illustrated in Fig. 4 and Fig. 5 and used for the network analysis are indicated by asterisks.

Fig. 3. Diatom community composition as determined by microscopic observations. Taxa with a relative abundance $\geq 1 \%$ of all diatoms in at least one sample are shown. Dates in bold correspond to the spring and summer blooms. The contribution of diatoms to total phytoplankton (> $10 \mu \mathrm{m}$ ) carbon biomass for the sampling dates are: 2016.10 .25 - 97\%; 2016.11.06 - 99\%; 2016.11.17 - 96\%; 2016.11.28 - 91\%; 2016.12.09 - 97\%; 2016.12.20 90\%; 2016.12.31 - 95\%; 2017.01.11 - 87\%; 2017.01.22 - 76\%; 2017.02.02 - 86\%; 2017.02.13 - 89\%; 2017.02.24 - 67\%. The complete list of diatom species is provided in Table S2.

Fig. 4. Heatmap of abundant prokaryotic ASVs determined by relative abundances ( $\geq 1 \%$ of total relative abundance in at least one sampling date) of the free-living community. Results 
of 12 time points sampled at 11-day interval and used for the network analysis are shown. The bloom time periods are indicated in bold. All 19 samples are illustrated on Fig. S4.

Fig. 5. Heatmap of abundant prokaryotic ASVs determined by relative abundances ( $\geq 1 \%$ of total relative abundance in at least one sampling date) of the particle-attached community. Results of 12 time points sampled at 11-day interval and used for the network analysis are shown. The bloom time periods are indicated in bold. ASVs presented in both free-living and particle-attached fractions are in italic. All 19 samples are illustrated on Fig. S5.

Fig. 6. Network between dominant diatoms, free-living and particle-attached prokaryotes based on significant associations detected by both extended local similarity analysis (eLSA) and Spearman correlations with significance P-value $\leq 0.05$ and Q-value $\leq 0.05$ in each. Green, red and purple squares denote diatoms, free-living and particle-attached prokaryotic ASVs, respectively. The solid and dashed lines represent positive and negative correlations, respectively. Lines with an arrow denote time-delayed correlations. Filled arrows indicate that the pattern of prokaryotic taxa is ahead of time with respect to that of diatoms $(\mathrm{D}>0)$. Open arrows indicate that the associated prokaryotic taxa are behind with respect to diatoms $(\mathrm{D}<0)$.

Delta and diamond arrows indicate time-lagged correlations with a delay of 1 and 2, respectively. The number following each prokaryote specifies the ASVs. Abbreviations of diatoms are as follows: Chae_deci Chaetoceros decipiens, Chae_Hyal Chaetoceros Hyalochaete, Core_iner Corethron inerme, Cyli_clos Cylindrotheca closterium, Euca_anta Eucampia antarctica, Frag_sepa Fragilariopsis separanda, Guin_cyli Guinardia cylindrus, Odon_weis Odontella weisflogii, Prob_alat Proboscia alata, Pseu_nitz Pseudo nitzschia, 
Rhiz_ante Rhizosolenia antennata, Rhiz_chunii Rhizosolenia chunii, Thal_anta Thalassiosira antarctica, Thal_grac Thalassiosira gracilis, Tham_nitz Thalassionema nitzschioides, Thax_anta Thalassiothrix antarctica. Abbreviations of prokaryotes are: Ascidi Ascidiaceihabitans, CytophaCyclo Cyclobacteriaceae, Plank Planktomarina, PlankTem Planktomarina temperata, RhodoSedi Sedimentitalea, Sphing Sphingomonas, SphingFlavimaris Sphingorhabdus flavimaris.

Fig. 7. Temporal changes in the relative abundance of abundant ASVs in the free-living fraction; Aurantivirga (ASV_6) and SAR92 (ASV_9)(a), Polaribacter (ASV_10) and Amylibacter (ASV_8)(b) and SAR11 (ASV_4) and SUP05 (ASV_5)(c). Green shaded area denotes satellite-based Chl $a$.

Fig. 8. Temporal changes in the concentration of inorganic nitrogen species $\left(\mathrm{NO}_{2}{ }^{-}\right.$- black circles, $\mathrm{NO}_{3}{ }^{-}$- white circles, $\mathrm{NH}_{4}{ }^{+}$- grey squares) (a) and the relative abundance of one ASV belonging to Pseudomonadales (ASV_2) (b) and two ASVs belonging to Nitrincolaceae (ASV_1 and ASV_7) (c). 


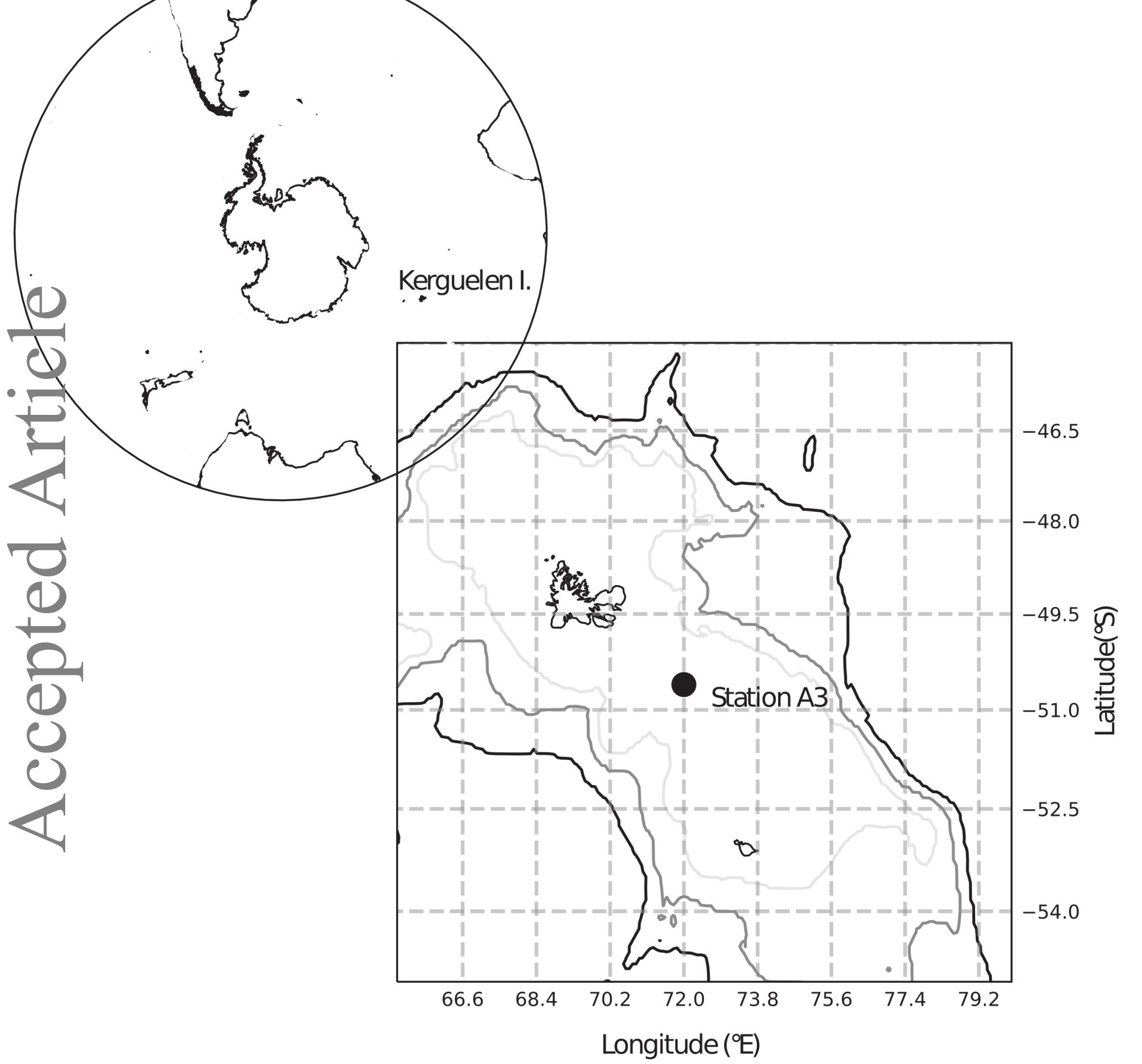

This article is protected by copyright. All rights reserved. 


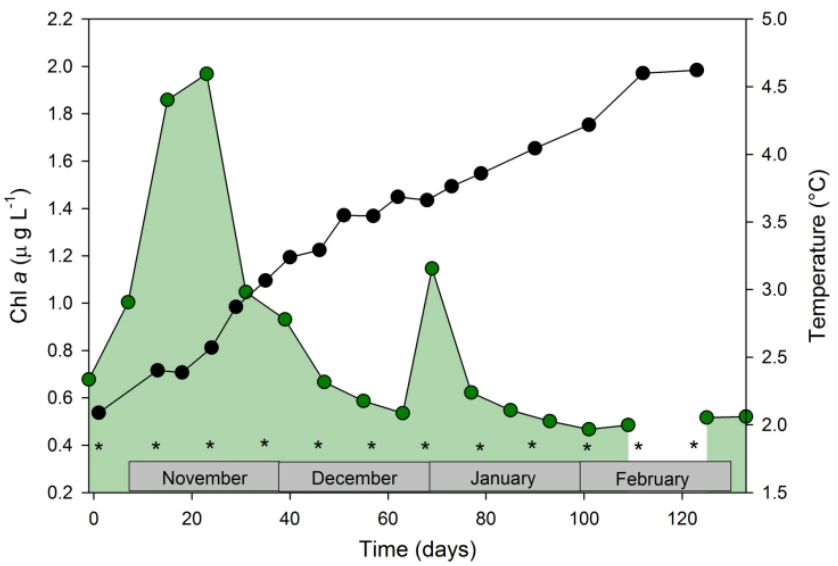

Fig. 2. Temporal changes of Chlorophyll a (green shaded area) and temperature (black circles) during the period of RAS deployment. Chlorophyll a is derived from ocean color satellite data; globcolor products are available at Copernicus Marine Service (http://marine.copernicus.eu). Sampling dates of prokaryotic community composition illustrated in Fig. 4 and Fig. 5 and used for the network analysis are indicated by asterisks.

$209 \times 296 \mathrm{~mm}(300 \times 300$ DPI) 


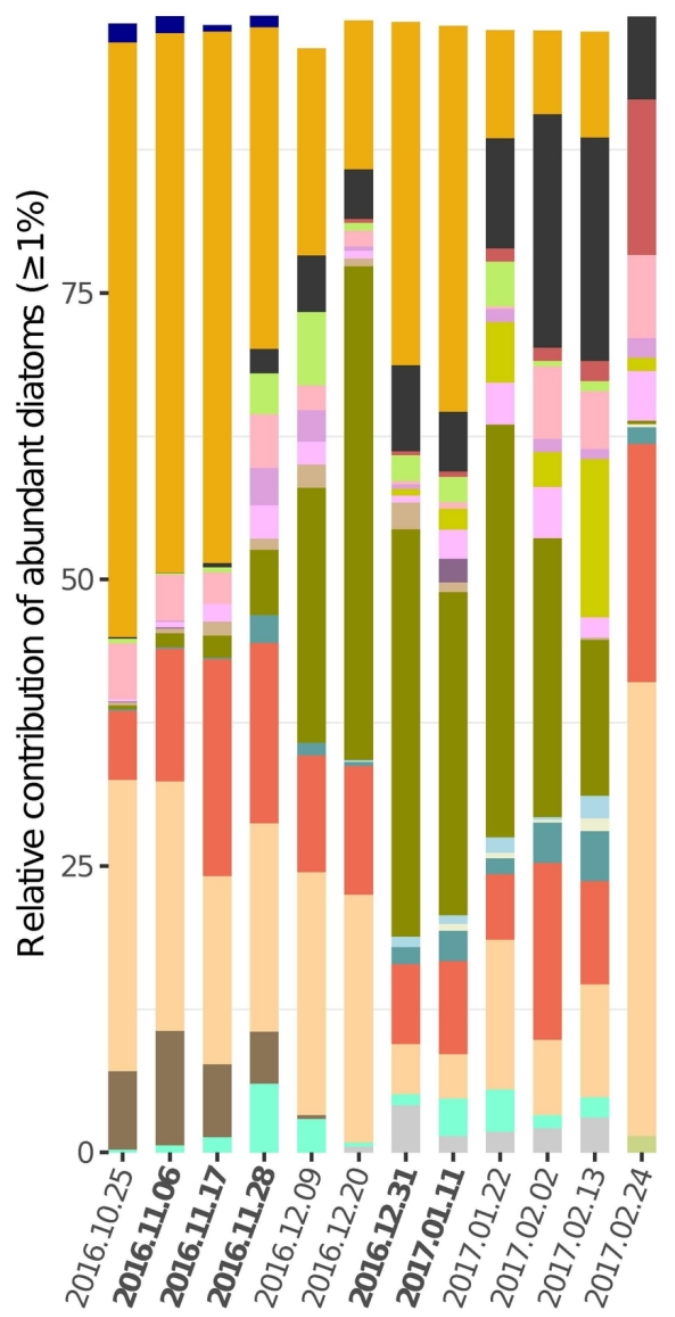

Chaetoceros decipiens
Chaetoceros Hyalochaete
Corethron inerme
Cylindrotheca closterium
Eucampia antarctica
Fragilariopsis kerguelensis

Fragilariopsis separanda/rhombica

Guinardia cylindrus

Navicula directa

Nitzschia longissima

Odontella weisflogii

Pseudo-nitzschia spp.

Proboscia alata

Rhizosolenia antennata f. semispina

Rhizosolenia chunii

Small Centric spp.

Thalassionema nitzschioides

Thalassiosira antarctica

Thalassiosira gracilis

Thalassiosira gravida

Thalassiothrix antarctica

Fig. 3. Diatom community composition as determined by microscopic observations. Taxa with a relative abundance $\geq 1 \%$ of all diatoms in at least one sample are shown. Dates in bold correspond to the spring and summer blooms. The contribution of diatoms to total phytoplankton ( $>10 \mu \mathrm{m})$ carbon biomass for the sampling dates are: 2016.10.25 - 97\%; 2016.11.06 - 99\%; 2016.11.17-96\%; 2016.11.28-91\%; 2016.12.09 - 97\%; 2016.12.20 - 90\%; 2016.12.31 - 95\%; 2017.01.11 - 87\%; 2017.01.22 - 76\%; 2017.02.02 - 86\%; 2017.02.13 - 89\%; 2017.02.24 - 67\%. The complete list of diatom species is provided in Table S2.

$142 \times 146 \mathrm{~mm}(300 \times 300 \mathrm{DPI})$ 


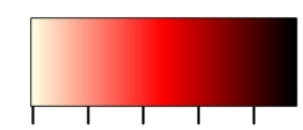

$\begin{array}{lllll}0.00 & 0.05 & 0.10 & 0.15 & 0.20\end{array}$
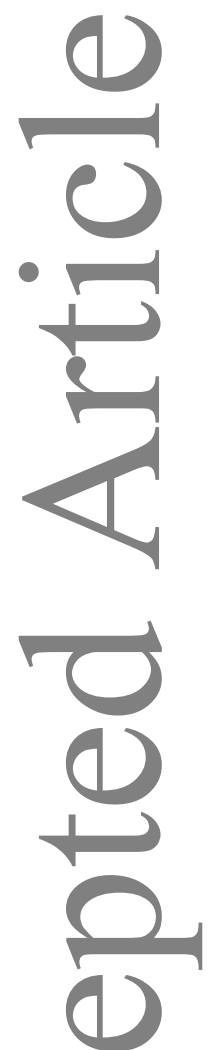

.

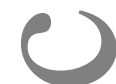

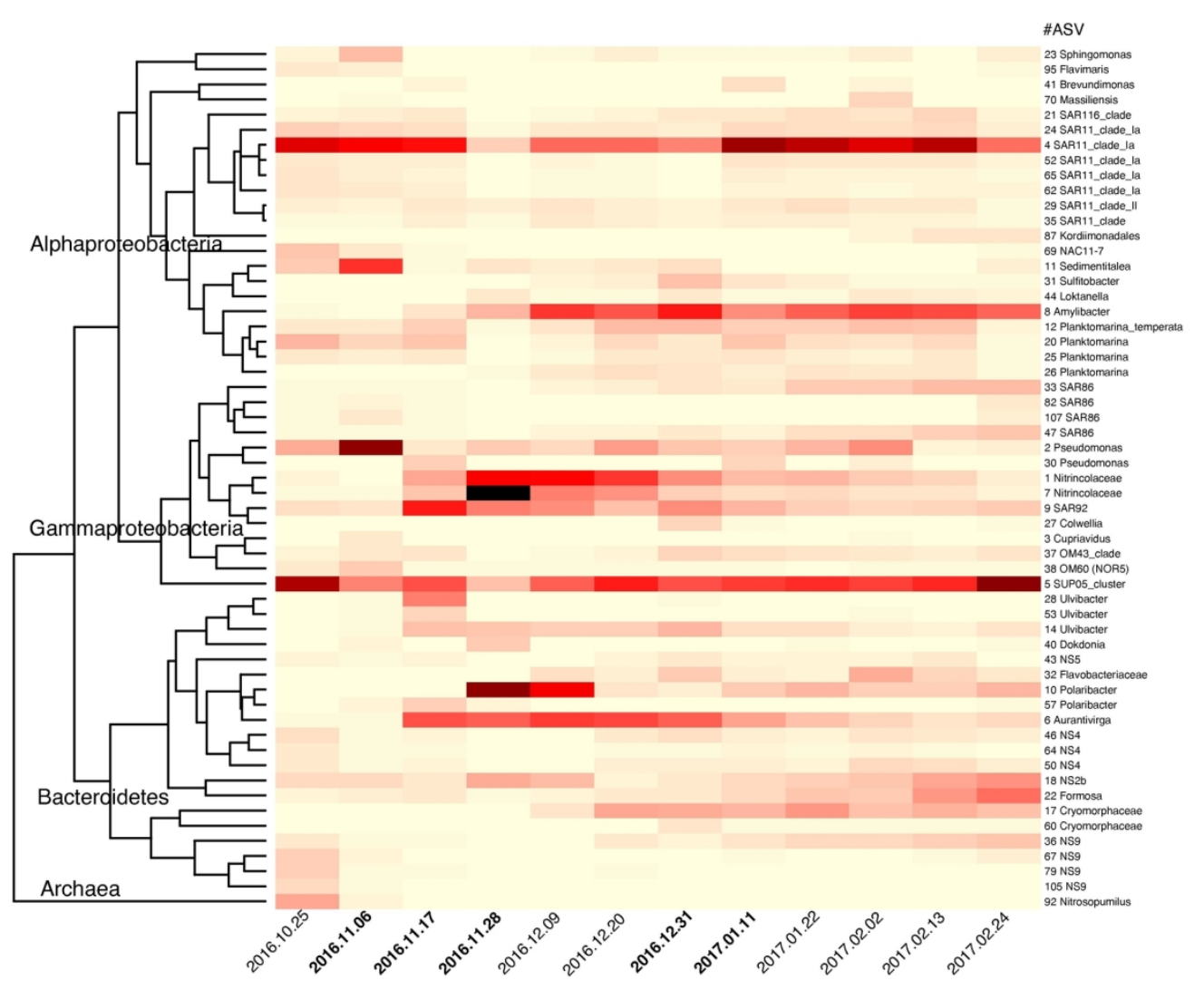

Fig. 4. Heatmap of abundant prokaryotic ASVs determined by relative abundances ( $\geq 1 \%$ of total relative abundance in at least one sampling date) of the free-living community. Results of 12 time points sampled at 11-day interval and used for the network analysis are shown. The bloom time periods are indicated in bold.

All 19 samples are illustrated on Fig. S4.

$$
154 \times 153 \mathrm{~mm}(300 \times 300 \text { DPI) }
$$



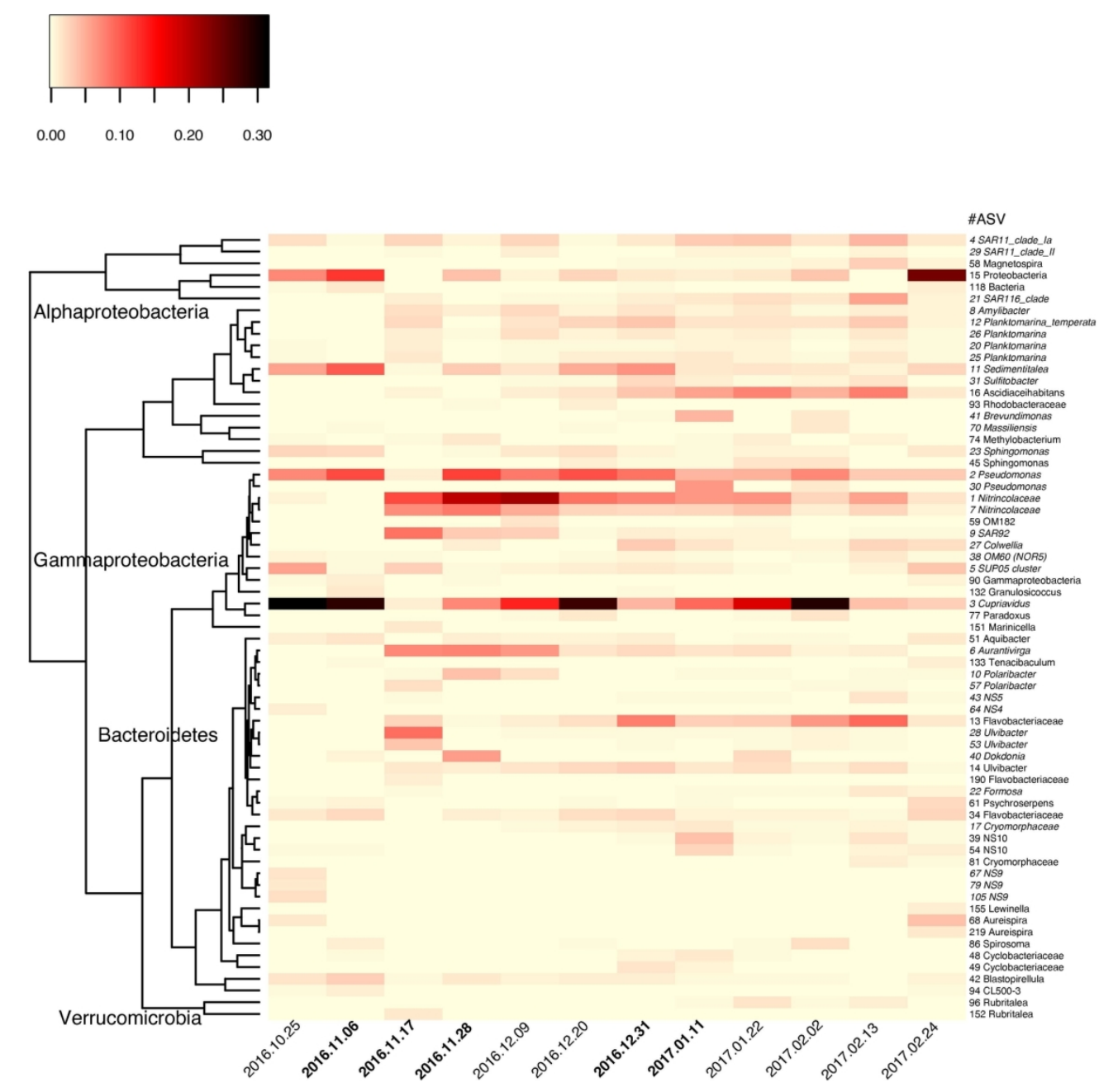

Fig. 5. Heatmap of abundant prokaryotic ASVs determined by relative abundances ( $\geq 1 \%$ of total relative abundance in at least one sampling date) of the particle-attached community. Results of 12 time points sampled at 11-day interval and used for the network analysis are shown. The bloom time periods are indicated in bold. ASVs presented in both free-living and particle-attached fractions are in italic. All 19 samples are illustrated on Fig. S5.

$154 \times 153 \mathrm{~mm}(300 \times 300 \mathrm{DPI})$ 


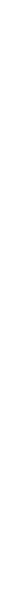



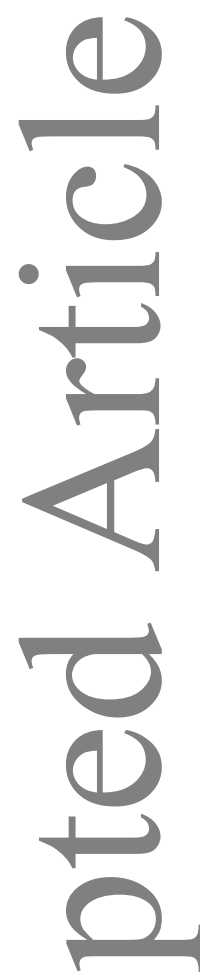

.

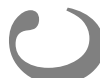

.

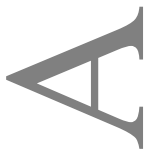

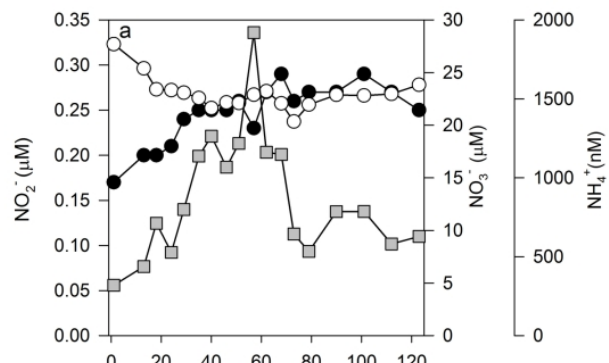
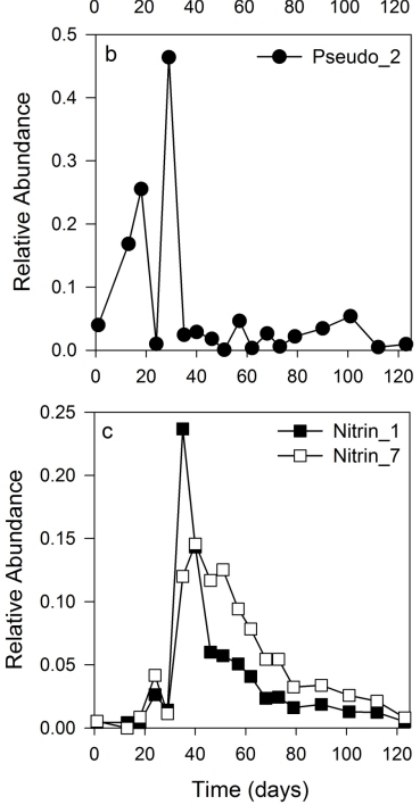

Fig. 8. Temporal changes in the concentration of inorganic nitrogen species (NO2- - black circles, NO3- white circles, $\mathrm{NH} 4+-$ grey squares) (a) and the relative abundance of one ASV belonging to Pseudomonadales (ASV_2) (b) and two ASVs belonging to Nitrincolaceae (ASV_1 and ASV_7) (c).

This article is protected by copyright. All rights reserved. 